\title{
Rhizoctonia solani damping-off on spring turnip rape and spring rape (Brassica spp.) in Finland
}

\author{
RISTO TAHVONEN*, JUKKA HOLLO*, ASKO HANNUKKALA \\ and AARNE KURPPA* \\ Institute of Plant Pathology, University of Helsinki \\ SF-00710 HELSINKI 71, Finland
}

\begin{abstract}
Damping-off occurred in $90 \%$ of the spring oilseed rape fields surveyed in 1981-1982. On the average, $10 \%$ of the plants were infected with damping-off. $6 \%$ of the fields were severely infected ( $>30 \%$ of the plants affected) by damping-off and $38 \%$ were uninfected or only slightly infected ( $\leq 5 \%$ of the plants affected). The incidence of dampingoff was higher in those fields which had been under oilseed rape in earlier years. In a crop rotation experiment, the amount of damping-off increased from $2 \%$ to $20 \%$, and finally to $38 \%$, depending upon whether turnip rape had been grown on the same part of the field once, twice or three times. Crops other than Cruciferous ones were grown for 1 or 3 years between the turnip rape crops. Rhizoctonia solani Kühn was isolated from $76 \%$ of the affected plants. The $R$. solani isolates produced severe damping-off on rape and turnip rape in pathogenicity tests. $R$. solani isolates from barley, potato and lettuce brought about only mild cases of damping-off, or else only a decrease in the growth of the plants. Fusarium avenaceum Sacc. was the only other isolated fungus which was pathogenic.
\end{abstract}

\section{Introduction}

The cultivation of spring turnip rape (Brassica campestris L. ssp. oleifera) and spring rape (Brassica napus L. var. oleifera) increased sharply in Finland during the 1970's. The area under these crops at the beginning of the 1980's has been around

* New adress: Agricultural Research Centre, Department of Plant Pathology, SF-31600 JOKIOINEN, Finland
$55000-60000$ ha, spring turnip rape accounting for over 50000 ha of this area. The yields of spring oilseed rape have remained stable under the varying growing conditions in Finland and oilseed rape has been considered to be extremely suitable as a break crop in cereal monoculture (KöYLIJÄRVI 1982).

The pathogens affecting spring turnip rape and spring rape under Finnish conditions have been largely neglected. In Sweden and 
elsewhere in Europe, Leptosphaeria maculans (Desm.) Ces. \& de Not, Sclerotina sclerotiorum de Bary and Alternaria spp. are the most serious pathogens affecting oilseed rapes. In addition to these, damping-off and foot rot are also serious pathogens in Canada (BERKENKAMP and VAARTNOU 1972, RAwLinson and Muthyalu 1979, Krüger 1979, SVENSSON 1982). In a long-term crop rotation experiment carried out by the Department of Plant Pathology, the University of Helsinki, damping-off started to increase strongly on turnip rape after the crop had been grown on the same area twice or three times. This led to the decision to determine whether the damping-off situation was the same with commercial crops of turnip rape and rape.

\section{Material and methods}

\section{The crop rotation experiment}

Spring turnip rape is included in two rotations in the crop rotation experiment being carried out by the Department of Plant Pathology at 'iikki.

In one of the rotations, turnip rape is grown on the same block of the experiment every second year. Either barley or wheat are used as the preceding crop. In the other rotation, spring turnip rape is grown on the same site every fourth year, the order of the crops in the cycle being turnip rape - barley/ wheat - oats - broad beans.

The experiment was established in 1977. During the period 1979-1982 the turnip rape variety was "Torch", and in 1979 the variety "Span" was used.

In 1979 a sample of 300 plant individual was analysed. Owing to the increase in the amount of damping-off, the number of analysed plants was increased during 1980-1982 to 1200 plants/year, i.e. 25 plants/sample plot. The analysis was carried out at the growth stage 2 (HARPER and BERKENKAMP 1975).
2. Collection of seedling samples from fields and their analysis

Samples of spring turnip rape and spring rape seedlings were collected from 62 fields in southern Finland in 1981 and 50 fields in 1982. There were usually $2-4$ true leaves on the seedlings at the time when they were collected. A single sample (about 400 seedlings) consisted of 4 subsamples which were taken from different points in the field. Each subsample consisted of about 100 seedlings which were collected from $2-4$ adjacent rows. Soil samples (10 litres/field) were also taken from the topsoil in 1981. In addition, information about the cultivation history of each field during the preceding four years was collected in 1981 .

The subsamples from each field were analysed separately. The growth stage of the seedlings was determined and the seedlings classified into three groups: healthy $=0$, infected $=1$ and dead $=2$. The damping-off $\%$ and disease index were calculated for each field as the mean of the subsamples.

Seedlings were grown in the soil samples at a high temperature $\left(+25^{\circ} \mathrm{C}\right)$ and a low temperature $\left(+11^{\circ} \mathrm{C}\right)$. Spring turnip rape of the "Torch" variety were used as the test plants. Plastic pots (1.5 l) were filled with the sample soil and 30 seeds sown in each at a depth of $2 \mathrm{~cm}$. A pot containing sterilised sand instead of soil was used as a control. There were three replications. After the plants had grown for three weeks they were classified in the same way as the seedling samples taken from the fields. Only 30 soil samples could be studied at the low temperature.

\section{Fungal isolations}

Fungal isolations were made on plants suffering from damping-off. A small piece of tissue was cut from the borderline between healthy and infected tissue. The specimen was surface sterilised for $30 \mathrm{~s}$ in $1 \% \mathrm{NaOCl}$ and then rinsed in $94 \%$ ethanol. When dry the specimens were transferred onto cornmeal 
agar (Difco) containing 100 ppm streptomycin (Streptomycin sulphate). The petri dishes were incubated at room temperature and the fungi which developed from the plant tissue were identified under a stereo and a light microscope after 7 days and after 21 days.

\section{Pathogenicity tests}

The pathogenicity of 16 fungal isolates to spring turnip rape and spring rape was tested in 1981. Seven out of the ten Rhizoctonia solani Kühn isolates were from spring turnip rape or spring rape. The other 3 Rhizoctonia solani isolates were obtained from potato, barley and lettuce.

The Fusarium species included in the test were Fusarium avenaceum Sacc., Fusarium culmorum Sacc. Fusarium oxysporum Schlecht. and Fusarium sambucinum Fuckel. In addition, the pathogenicity of Ulocladium consortiale (Tühm.) Simmons and Preussia aemulans (Rehm) v. Arx was tested. The latter fungus was isolated from each of the spring turnip rape seedlings suffering from damping-off which were growing on one field in Halikko.

The pathogenicity test was carried out both in a Jacobsen germinator and as a pot experiment in the greenhouse. The fungal isolates for the test were grown for one week on PDA medium (Difco) in 9-cm Petri dishes.

The test plants used in the Jacobsen germinator were spring turnip rape "Span». The seeds were immersed in an aqueous suspension (1 petri dish/100 ml sterile water) of the test fungus. When the infected seeds were dry they were sown in the Jacobsen germinator. The control seeds were immersed in an aqueous suspension of the growth medium. There were four replications of each fungus (25 seeds/replication). The germination of the seeds and condition of the seedlings was checked 7 and 10 days after sowing.

Fresh peat was used as the growing medium in the greenhouse. An aqueous sus- pension (1 Petri dish/100 ml sterile water) was mixed into plastic boxes $(50 \times 25 \times$ $9,5 \mathrm{~cm}$ ), each containing 7 litres of peat.

In the control treatment a mixture of water and the growth medium was added to the peat. After being innoculated, the boxes were kept in the greenhouse for one week and the test seeds then sown in the boxes. The spring turnip rape varieties "Span" (0-variety), "WW-1644» (00-variety) and "Candle» (000-variety), and the spring rape variety "Oro" were used as the test plants. One row of seeds of each variety were sown in each box ( 30 seeds/row). The seedlings were grown until they reached the $3-4$ leaf stage. The number of seedlings which developed was counted weekly. The mean temperature throughout the experiment was $+20^{\circ} \mathrm{C}$. At the end of the experiment the height of the seedlings from the root collar to the tip of the uppermost leaf was measured and the degree of infection determined according to the previously described criteria.

\section{Statistical treatment}

The number of seedlings suffering from pre-emergence damping-off was calculated in the pot experiment as the differences in emergence between the control and test treatments. Seedlings killed by pre-emergence damping-off were placed in group 2 of the disease scale.

The fields were classified into four groups on the basis of the incidence of damping-off: $0-5 \%, 6-15 \%, 16-30 \%$ and over $30 \%$.

A value weighted on the basis of the cultivation history of the field was given for the cultivation of oil seed crops. The more frequent and the closer to 1981 that oil seed crops had been grown in the field, the larger was the weighted value (Table 3).

The material was tested using the Student's t-test, analysis of variance and regression analysis. The differences between the different treatments were analysed by means of LSD in cases where the F value obtained in analysis of variance was statistically signif- 
icant. The degree of statistical significance is denoted as follows: $\mathrm{P} \leq 0.05=+, \mathrm{P} \leq$ $0.01=++$, and $\mathrm{P} \leq 0.001=+++$.

\section{Results}

\section{The symptoms of damping-off}

The initial symptoms of post-emergence damping-off are a partial darkening of the hypocotyl and radicle of the turnip rape or
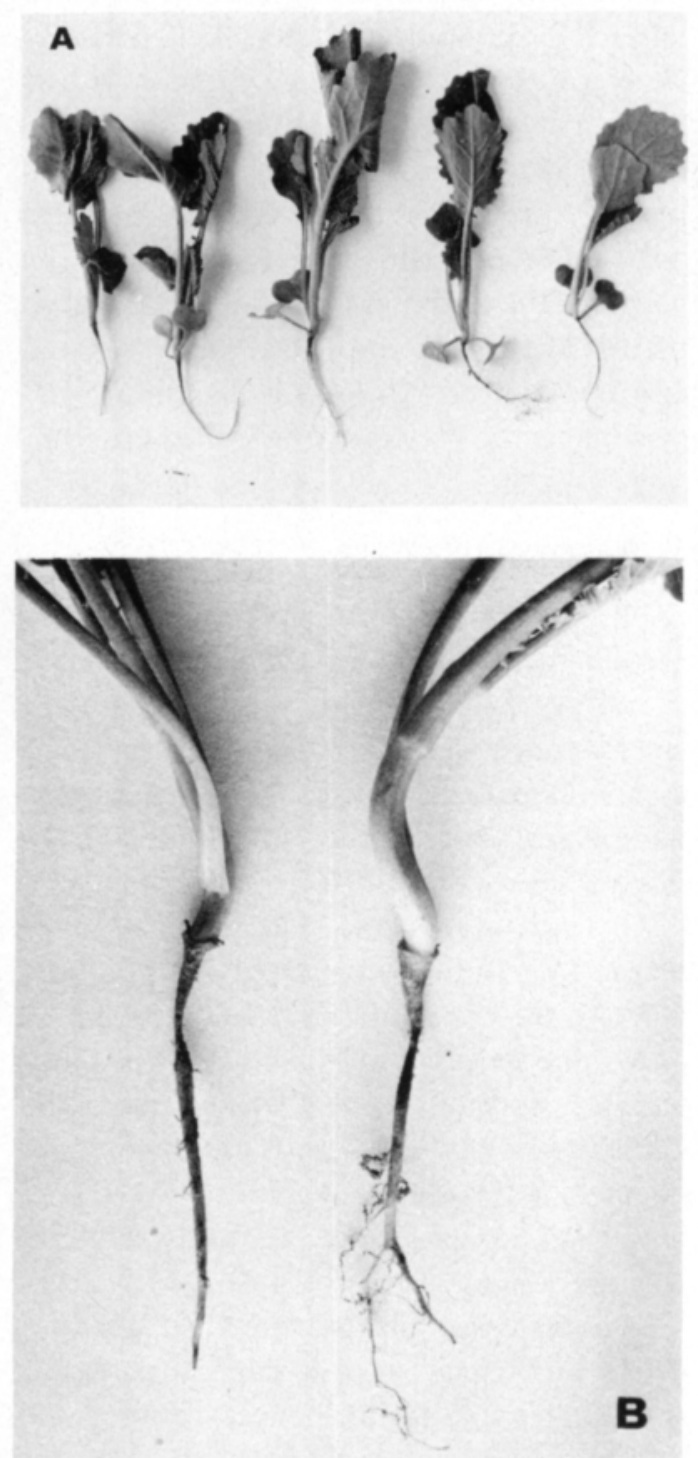

Fig. 1. Damping-off caused by Rhizoctonia solani on turnip rape, a) on germlings, b) large damaged plants. rape seedlings. As the disease progresses the whole of the hypocotyl becomes dark and shrinks to form a thread-like strand. (Fig. 1). The plants are either killed off by the post-emergence damping-off or recover to some extent as a result of secondary growth of the hypocotyl, but remain poorly developed. Pre-emergence damping-off is only evident as a poor plant stand.

\section{Incidence of damping-off}

In the crop rotation experiment, spring turnip rape was grown as the first and second crop on the same experimental block in the longer crop rotation, and as the second and third crop in the shorter crop rotation during 1979-1982. The number of plants suffering from damping-off increased in both crop rotations as the number of times spring turnip rape was grown on the same site increased (Table 1). When turnip rape was grown for the second time on the same block the number of plants suffering from damping-off increased to about $20 \%$, and when it was cultivated for the third time the number of damping-off seedlings was already about $38 \%$.

Damping-off occurred on 56 of the 62 fields examined in 1981 and on 46 of the 50 fields in 1982. The mean number of seedlings affected by damping-off on the fields in each year was about $10 \%$. About $20 \%$ of the fields in both years had a damping-off rate of $16-30 \%$ of the seedlings, and $6 \%$ of the fields had a damping-off rate of over $30 \%$ (Fig. 2a). There were no regional differences as regards the incidence of damping-off. The mean number of seedlings suffering from damping-off in spring turnip rape fields was $9.5 \%$, and in spring rape fields $12 \%$. There were considerable differences in the incidence of damping-off in the subsamples from the same fields.

It was also possible to estimate the amount of pre-emergence damping-off in the experiments in which seedlings were grown in the soil samples collected in 1981. The incidence 
Table 1. The occurrence of damping-off on spring turnip rape in the crop rotation experiment during $1979-1982$.

\begin{tabular}{|c|c|c|c|c|}
\hline \multirow[t]{3}{*}{ Crop rotation } & \multirow[t]{3}{*}{ Year } & \multicolumn{3}{|c|}{$\begin{array}{l}\text { Number of times turnip rape } \\
\text { grown on the same area }\end{array}$} \\
\hline & & 1. & 2. & 3. \\
\hline & & \multicolumn{3}{|c|}{ Damping-off $\%$} \\
\hline \multirow[t]{5}{*}{ Turnip rape - cereal - turnip rape etc. } & 1979 & - & 16,0 & - \\
\hline & 1980 & - & 22,0 & - \\
\hline & 1981 & - & - & 54,8 \\
\hline & 1982 & - & - & 20,5 \\
\hline & & - & 19,0 & 37,7 \\
\hline \multirow{5}{*}{$\begin{array}{l}\text { Turnip rape }- \text { cereal }- \text { cereal }- \\
\text { broad bean }- \text { turnip rape etc. }\end{array}$} & 1979 & 3,0 & - & - \\
\hline & 1980 & 1,5 & - & - \\
\hline & 1981 & - & 35,3 & - \\
\hline & 1982 & - & 11,5 & - \\
\hline & & 2,3 & 23,4 & - \\
\hline
\end{tabular}

of damping-off was $18 \%$ at the higher temperature, and $26 \%$ at the lower temperature. (Fig. 2b). The proportion of preemergence damping-off was considerably greater at the lower temperature than at the higher one (Table 2).

Information was collected in 1981 about the cultivation history of 38 fields. Spring

A
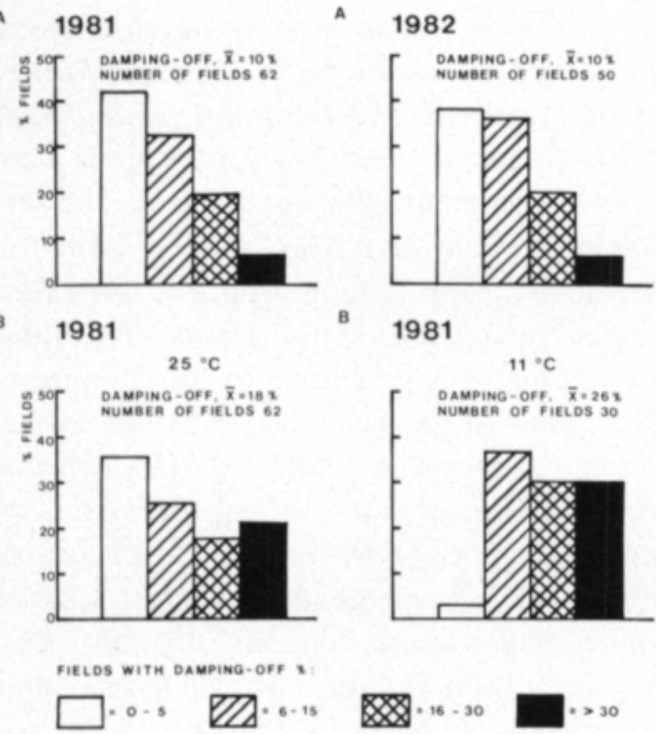

Fig. 2. The abundance of damping-off on spring turnip rape and spring rape in 1981 and 1982 . A) on the basis of seedling samples taken from the fields, B) in seedling growing experiments carried out at temperatures of $25^{\circ} \mathrm{C}$ and $11^{\circ} \mathrm{C}$ in soil samples collected in 1981 .
Table 2. Effect of a high and a low growing temperature on the amount of damping-off in spring turnip rape seedlings. Mean of 30 soil samples.

\begin{tabular}{lcc}
\hline & $\begin{array}{c}\text { Post-emergence } \\
\text { damping-off } \\
\%\end{array}$ & $\begin{array}{c}\text { Pre-emergence } \\
\text { damping-off } \\
\%\end{array}$ \\
\hline $\begin{array}{l}\text { High temperature } \\
+25^{\circ} \mathrm{C}\end{array}$ & 14,9 & 4,8 \\
Low temperature & & \\
$+11^{\circ} \mathrm{C}$ & 11,5 & 14,9 \\
\hline $\begin{array}{l}\text { Difference } \\
\text { t-value }\end{array}$ & 3,4 & $-10,1$ \\
\hline
\end{tabular}

turnip rape or spring rape had been grown at least once on most of the fields during the previous four years, which indicates that spring oil seed crops are very frequently grown on the same area (Table 3 ). On the basis of the experiments involving the growing of seedlings at higher temperatures, the amount of damping-off increased as the weighted value for the cultivation of oil seed crops increases (Fig. 3). The incidence of damping-off varied between wide limits in the case where oilseed rape had been grown in the fields during the preceding four years. If oilseed rape had not been grown in the fields during the preceding four years, the incidence of damping-off was low. 
Table 3. Distribution of the number of times oil seed crops were grown and the weighted value for the cultivation of oilseed rape in the sample fields in 1981.

\begin{tabular}{lcccccc}
\hline $\begin{array}{l}\text { Crop } \\
1977\end{array}$ & 1978 & 1979 & 1980 & \multicolumn{2}{c}{$\begin{array}{c}\text { Number of fields } \\
\%\end{array}$} & $\begin{array}{c}\text { Weighted value for, } \\
\text { oilseed rape }^{2}\end{array}$ \\
\hline 0 & 0 & 0 & 0 & 10 & 26,3 & 0 \\
0 & 1 & 0 & 0 & 8 & 21,1 & 2 \\
1 & 1 & 0 & 0 & 1 & 2,6 & 3 \\
0 & 0 & 1 & 0 & 7 & 18,4 & 3 \\
1 & 0 & 1 & 0 & 1 & 2,6 & 4 \\
0 & 1 & 1 & 0 & 3 & 7,9 & 5 \\
0 & 0 & 0 & 1 & 2 & 5,3 & 4 \\
0 & 1 & 0 & 1 & 1 & 2,6 & 6 \\
1 & 1 & 0 & 1 & 1 & 2,6 & 7 \\
0 & 0 & 1 & 1 & 2 & 5,3 & 7 \\
0 & 1 & 1 & 1 & 2 & 5,3 & 9 \\
\hline
\end{tabular}

1 = spring turnip rape or spring rape, 0$)=$ other crop (mainly cereals).

2 The weighted value for the cultivation of oil seed rape was obtained by multiplying the value for the 1977 crop by 1 , for the 1978 crop by 2 , for the 1979 crop by 3 and the 1980 crop by 4 , and then adding the results together.

4. Fungal isolations from plants suffering from damping-off

The fungus most frequently isolated from spring turnip rape and spring rape plants suffering from damping-off was Rhizoctonia

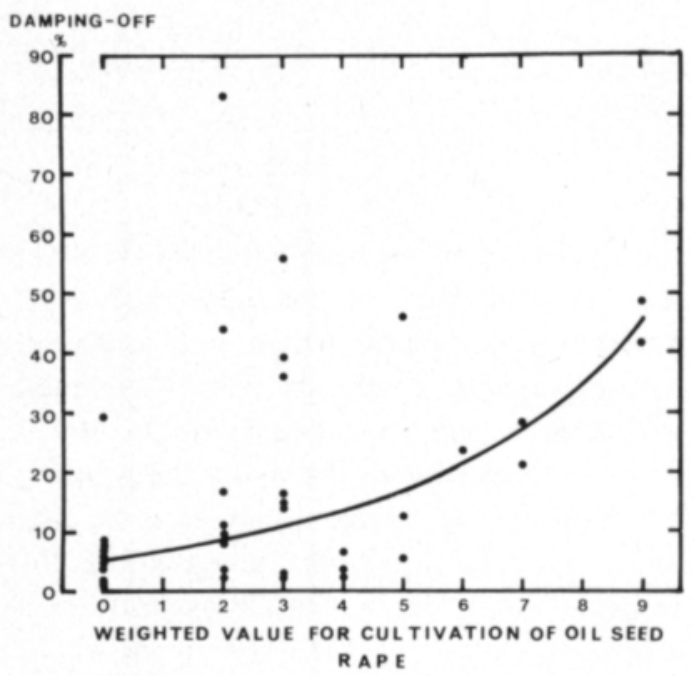

Fig. 3. Dependence of the incidence of damping-off on the cultivation of oil seed crops. The damping-off observations are from seedling growing experiments using soil samples at $25^{\circ} \mathrm{C}$. The figures are for both pre-emergence and post-emergence damping-off. $\mathrm{y}=5.15 \mathrm{e}^{0.24 \mathrm{x}}, \mathrm{r}=0.52^{+++}$ solani Kühn (Table 4). The fungus was identified on the basis of the colour and morphological characteristics of the mycelia and sclerotia. There were no differences in the occurrence of Rhizoctonia solani in different years.

Fusarium fungi which were most frequently isolated were Fusarium avenaceum Sacc., Fusarium culmorum Sacc., Fusarium oxysporum Schlecht. and Fusarium sambucinum Fucel. None of these Fusarium species were clearly dominant. The species from the following genera were also isolated from the seedlings: Gliocladium spp., Ulocladium spp., Penicillium spp., Mucor spp. and Chaetomium spp. and more rarely species belonging to the genera of Absidia, Alternaria, Aspergillus, Botrytis, Cephalosporium, Chrysosporium, Cladosporium, Coniothyrium, Cylindrocarpon, Dendryphion, Graphium, Humicola, Monodictys, Mortieriella, Papulaspora, Phoma, Preussia, Rhizopus, Thamnidium, Trichoderma and Torula.

\section{Pathogenicity tests}

All the Rhizoctonia solani isolates obtain- 
Table 4. The fungi most frequently isolated from turnip rape and rape suffering from damping-off.

\begin{tabular}{|c|c|c|c|c|}
\hline & \multicolumn{4}{|c|}{$\%$ of the isolations } \\
\hline & \multirow{2}{*}{$\begin{array}{c}\text { Crop rotation } \\
\text { experiment } \\
1979-1982\end{array}$} & \multirow[t]{2}{*}{$\begin{array}{c}\text { Field samples } \\
1981-1982\end{array}$} & \multicolumn{2}{|c|}{$\begin{array}{l}\text { Seedling culti- } \\
\text { vation } 1981\end{array}$} \\
\hline & & & $25^{\circ} \mathrm{C}$ & $11^{\circ} \mathrm{C}$ \\
\hline Rhizoctonia solani & 89,7 & 62,3 & 80,1 & 71,7 \\
\hline Fusarium spp. & 5,0 & 11,4 & 19,2 & 7,4 \\
\hline Gliocladium spp. & 7,9 & 1,6 & 8,1 & 5,2 \\
\hline Ulocladium spp. & 1,5 & 1,2 & 3,3 & 2,1 \\
\hline Penicillium spp. & 6,2 & 2,7 & 4,2 & 5,7 \\
\hline Mucor spp. & 7,3 & 12,2 & 2,3 & 2,3 \\
\hline Chaetomium spp. & 2,2 & 1,4 & 2,9 & 4,7 \\
\hline Other fungi & 11,3 & 5,9 & 14,0 & 7,0 \\
\hline Number of isolations & 406 & 1330 & 307 & 191 \\
\hline
\end{tabular}

ed from the turnip rape and rape plants were pathogenic to the test plants (Fig. 4). They almost completely prevented the development of the seedlings on the peat substrate in the greenhouse (Table 5). In the case of the experiment with the Jacobsen germinator, three of the Rhizoctonia solani isolates were weaker pathogens than the other four which were isolated from turnip rape and rape. The Rhizoctonia solani isolate obtained from potato was not pathogenic in either of the tests. The Rhizoctonia solani isolate from

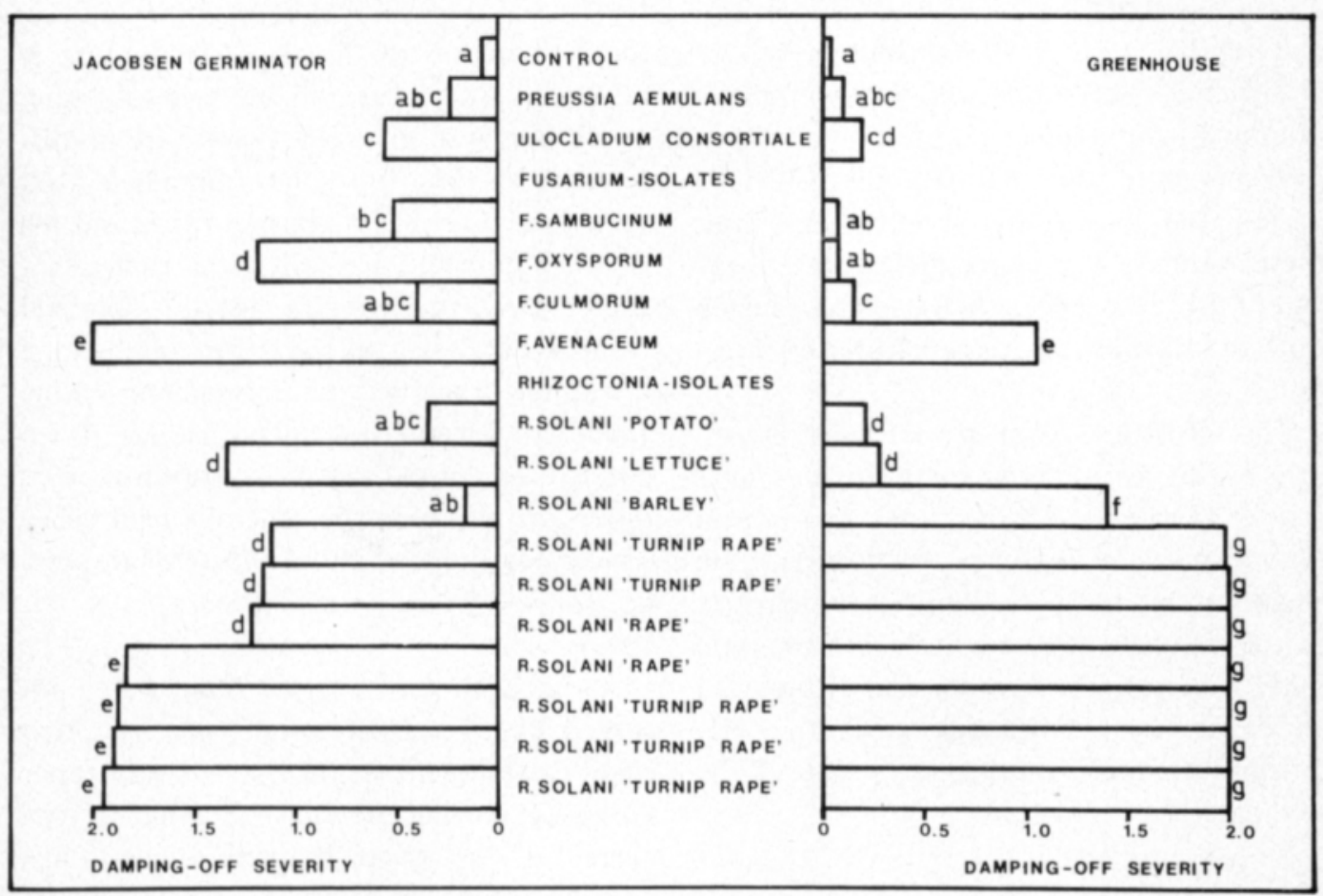

Fig. 4. The pathogenicity of the fungal isolations to spring turnip rape and spring rape determined in a Jacobsen germinator and in peat substrate in the greenhouse. $\mathrm{F}$ values: Jacobsen germinator, fungi $=25,1^{* * *}$, Greenhouse, fungi $=100^{* * *}$, varieties $=3,5$, fungi $\times$ varieties $=1,2$. If there is the same letter at the top of two columns, then there is no significant difference $(P=0,05)$ as regards the degree of infection. 
lettuce was pathogenic in the Jacobsen germinator but not in the peat substrate. On the other hand, the Rhizoctonia solani isolate from ba:ley was pathogenic in the peat substrate but not in the Jacobsen germinator.

As far as the Fusarium species were concerned, Fusarium avenaceum was pathogenic in both tests. Fusarium oxysporum was pathogenic in the Jacobsen gemination but not in the peat substrate. Fusarium culmorum, Fusarium sambucinum, Ulocladium consortiale (Tühm) Simmons and Preussia aemulans (Rhem) v. Arx did not exhibit any pathogenicity.

The interaction for pre-emergence damping-off between the fungi and the plant varieties in the pathogenicity test carried out in the peat substrate was statistically significant. Pre-emergence damping-off occurred most in Oro spring rape and least in the number variety WW-1644 (Table 5). Fusarium avenaceum caused the most preemergence damping-off to the Oro variety, and less damage to WW-1644 than to the other varieties. The Rhizoctonia solani isolates obtained from potato and barley caused less pre-emergence damping-off to the WW-1244 variety than to the other varieties. However, there were no significant differences at the end of the test between the varieties of turnip rape and rape as regards the degree of infection.

The seedlings grown in peat substrate infected with Rhizoctonia solani isolates were shorter (Table 6). All the fungi, apart from Fusarium sambucinum, clearly decreased the height growth of the seedlings in comparison to the controls. Although the Rhizoctonia solani isolates from potato and lettuce did not cause very much damping-off, they significantly reduced the height growth of the seedlings.

\section{Discussion}

Rhizoctonia solani Kühn was found to be the most common and most pathogenic fungal pathogen causing damping-off on spring turnip rape and spring rape. The fungus is polyphagic and a number of strains with varying properties are known (MorduE 1974). In Finland, $R$. solani causes diseases on cereal and grass crops and on potato (YlimäKI 1967, SepPänen 1979, MÄKelä \& PARIKKA 1980). It has earlier been found to be a causal agent of damping-off in greenhouse cultivations (LinNasalmi 1952). $R$. solani has also been found to be pathogenic to turnip rape and rape in Europe and in Canada (RAABE 1939, BerkenKAMP \& VAART. NOU 1974). After the seedling stage has been reached, $R$. solani has been frequently isolated from turnip rape and rape suffering from foot rot (Petrie 1974, Krüger 1979).

All the tested $R$. solani isolates from spring turnip rape and spring rape were exceedingly pathogenic. The difference between the pathogenicity of these isolates in the Jacobsen germinator may be due to the nutrient requirements of the isolates. An external source of nitrogen is an important factor in infection by $R$. solani (WEINHOLD et al. 1972). In the case of the peat substrate, which is rich in nitrogen, there were no differences between the isolates obtained from spring turnip rape and spring rape, and the isolate obtained from barley was also pathogenic. Behaviour of the isolate obtained from lettuce was, on the other hand, quite the opposite as it was pathogenic only in the Jacobsen germination. The isolate from potato was not pathogenic to turnip rape or rape. This supports the generally held belief concerning the specialised nature of $R$. sola$n i$ isolates from potato (PARMETER et al. 1969).

As far as the other tested fungi were concerned, only Fusarium avenaceum Sacc. was clearly pathogenic to turnip rape and rape. However, owing to the fact that it occurred in very small numbers only, its importance as a causal agent of damping-off was small. As it appears, according to $\mathrm{T}_{\mathrm{AH}}$ VONEN (1979) and the results of this study concerning the isolations made on plants af- 
Table 5. Pre-emergence damping-off on turnip rape and rape in the pathogenicity tests carried out in the peat substrate.

\begin{tabular}{|c|c|c|c|c|c|}
\hline \multirow[t]{3}{*}{ Fungus } & \multicolumn{5}{|c|}{ Pre-emergence damping-off $\%$} \\
\hline & \multicolumn{3}{|c|}{ Turnip rape } & \multirow{2}{*}{$\frac{\text { Rape }}{\text { Oro }}$} & \multirow[b]{2}{*}{ Mean } \\
\hline & $\begin{array}{c}\text { Span } \\
\text { 0-variety }\end{array}$ & $\begin{array}{l}\text { WW-1644 } \\
\text { 00-variety }\end{array}$ & $\begin{array}{c}\text { Candle } \\
\text { 000-variety }\end{array}$ & & \\
\hline Rhizoctonia solani "turnip rapen* & 98,8 & 98,6 & 99,6 & 99,7 & 99,2 \\
\hline Rhizoctonia solani »barley» & 31,9 & 10,0 & 31,7 & 28,8 & 25,6 \\
\hline Rhizoctonia solani "potato» & 12,9 & 1,0 & 17,3 & 11,1 & 10,6 \\
\hline Rhizoctonia solani wlettuce" & 8,6 & 0,0 & 3,8 & 5,6 & 4,5 \\
\hline Fusarium avenaceum & 13,0 & 4,0 & 18,3 & 33,3 & 17,1 \\
\hline Fusarium culmorum & 12,0 & 2,0 & 0,0 & 5,6 & 4,9 \\
\hline Fusarium oxysporum & 5,2 & 0,0 & 0,0 & 7,4 & 3,1 \\
\hline Fusarium sambucinum & 5,2 & 0,0 & 1,0 & 5,6 & 1,4 \\
\hline Ulocladium consortiale & 9,5 & 1,0 & 5,8 & 14,8 & 7,8 \\
\hline Preussia aemulans & 7,7 & 0,0 & 0,0 & 7,4 & 3,8 \\
\hline Control & 0,0 & 0,0 & 0,0 & 0,0 & 0,0 \\
\hline Mean & 46,9 & 41,6 & 45,6 & 48,1 & \\
\hline
\end{tabular}

* mean of 7 isolates

F values: fungi $>100^{+++}$, varieties $=15,8^{+++}$and fungi $\times$varieties $=2,2+++$.

LSD $(P=0,05)$ fungi $=3,4 \%$, varieties $=2,0 \%$ and variety with the same fungus $=8,2 \%$.

Table 6. Effect of the fungal isolates on the height growth of spring turnip rape and spring rape in the pathogenicity tests carried out on the peat substrate.

\begin{tabular}{|c|c|c|c|c|c|}
\hline \multirow[t]{3}{*}{ Fungus } & \multicolumn{5}{|c|}{ Seedling height $(\mathrm{cm})$} \\
\hline & \multicolumn{3}{|c|}{ Turnip rape } & \multirow{2}{*}{$\begin{array}{c}\text { Rape } \\
\text { Oro }\end{array}$} & \multirow[b]{2}{*}{ Mean } \\
\hline & Span & WW-1644 & Candle & & \\
\hline Control & 11,9 & 11,8 & 12,0 & 11,7 & $11,9 \mathrm{a}^{1}$ \\
\hline Fusarium sambucinum & 11,9 & 12,2 & 11,4 & 11,6 & $11,8 \mathrm{a}$ \\
\hline Fusarium oxysporum & 10,8 & 10,7 & 10,4 & 10,9 & $10,7 \mathrm{~b}$ \\
\hline Fusarium culmorum & 10,2 & 10,7 & 10,5 & 10,6 & $10,5 \mathrm{~b}$ \\
\hline Ulocladium consortiale & 10,8 & 9,9 & 9,6 & 10,2 & $10,1 \mathrm{~b}$ \\
\hline Preussia aemulans & 9,6 & 10,5 & 9,6 & 10,0 & $10,0 \mathrm{~b}$ \\
\hline Fusarium avenaceum & 10,7 & 9,1 & 7,3 & 8,9 & $9,0 \mathrm{c}$ \\
\hline Rhizoctonia solani slettuce" & 8,7 & 8,6 & 7,6 & 7,9 & $8,2 \mathrm{~cd}$ \\
\hline Rhizoctonia solani "potato" & 7,7 & 8,0 & 6,6 & 7,5 & $7,4 \mathrm{~d}$ \\
\hline Rhizoctonia solani "barley" & 4,8 & 4,3 & 3,4 & 4,0 & $4,1 \mathrm{e}$ \\
\hline \multicolumn{6}{|l|}{ Rhizoctonia solani wturnip rape } \\
\hline and rape» & 0 & 0 & 0 & 0 & 0 \\
\hline
\end{tabular}

F values: fungi $=63,04^{+++}$, varieties $=6,4^{++}$and fungi $\times$varieties $=1,05$.

' If two mean values are followed by the same letter, then the means do not differ significantly $(\mathrm{P}=0,05)$ from each other.

fected by damping-off, that the importance of seed-borne fungi is of only slight importance in Finland, thiram dusting which is widely used here is of dubious usefullness.
No information was obtained about preemergence damping-off when collecting the plant samples from the experimental plots and the fields used in commercial farming. 
In LinNaSALmI's (1952) experiments, for instance, $R$. solani caused a considerable amount of pre-emergence damping-off. The proportion of pre-emergence damping-off was considerably large in the case of seedlings grown in soil taken from fields, especially at a low temperature. The low temperature used in the experiments is quite equivalent to the mean soil temperature after sowing dates in Finland. This indicates that a plant stand of spring oilseed rape may be reduced as a result of pre-emergence dampingoff. The large variance in the subsamples also indicates that the pathogen is present in the soil in patches. The patchy occurrence of the disease caused by $R$. solani is due to the growth pattern of the fungus in the soil (BAKER et al. 1967). In addition to reducing the plant stand, the initial development of the seedlings can also be slowed down. This was reflected in the pathogenicity tests as slower growth of the seedlings. $R$. solani has been found to slow down the initial development of soy beans, although there were no clear symptoms of the disease (Grau \& MAR. TINSON 1979). The sparse stands of turnip rape and rape, and their slow initial development, weakens their ability to compete with weed plants (KöYLIJÄrvi and TULISALO 1982).

According to the results of the crop rota-

\section{References}

Baker, K. F., Flentje, N. T., Olsen, C. M. \& Stretton, H. M. 1967. Effect of antagonist on growth and survival of Rhizoctonia solani in soil. Phytopath. 57: 591-597.

Berkenkamp, B. \& VaARTNOU, H. 1972. Fungi associated with rape root rot in Alberta. Can. J. Pl. Sci. 52: 973-976.

Grau, C. R. \& Martinson, C. A. 1979. Inhibition of soybean hypocotyl elongation by Rhizoctonia solani. Phytopath. 69: 706-709.

Harper, F. R. \& Berkenkamp, B. 1975. Revised growth-stage for Brassica campestris and B. napus. Can. J. Pl. Sci. 55: 657-658.

KROGER, W. 1979. Verbreitung der Wurzelhals- und Stengelfăule (verursacht durch Phoma lingam) bei tion experiment and the field observations, the incidence of damping-off clearly increased as the number of times spring turnip rape and spring rape were grown on the same site increased. It was possible to explain $27 \%$ of the variation in the incidence of damping-off in the fields by means of the weighted value for oil seed crops. In the crop rotation experiment, the incidence of damping-off increased in both rotations, although spring turnip rape was grown on the same area only every fourth year in the longer rotation cycle. Furthermore, the $R$. solani isolate obtained from barley was pathogenic to spring turnip rape and to spring rape. These observations indicate a need for further studies into the behaviour of $R$. solani in cereal oilseed rape rotations. In addition, the role of $R$. solani as a causal agent of foot rot on spring oilseed rape in Finland should also be studied, as well as the effect of Rhizoctonia diseases on the yield from spring oilseed rape.

Acknowledgements. We extend our sincere thanks to Raision tehtaat, and especially to Tuula Laukkanen, M.Sc., and Mrs Pirkko Koivula who assisted in collecting the soil and seedling samples and who enabled additional information to be obtained from the farms in question.
Raps in der Bundesrepublik Deutschland. Nachr. bl. Deut. Pfl.schutz 31: 145-148.

KoYluJĀrVI, J. 1982. Rypsi ja rapsi viljan vaihtoehtona. Koetoim. ja Käyt. 9. 3. 1982 p. 10.

-, Tulusalo, U. 1982. Rypsi ja rapsi. Lannoitus, muokkaus ja kylvő. Koetoim. ja Käyt. 9. 3. 1982. p. 15.

Linnasalmi, A. 1952. Damping-off on herbaceous vegetables and ornamental plants grown under glass in Finland. Ann. Bot. Soc. Vanamo 26: 1-120.

Mordue, J. E. M. 1974. Thanatephorus cucumeris. C. M. I. Descriptions of pathogenic Fungi and Bacteria No. 406.

Măkelä, K. \& ParikKa, P. 1980. Root and foot rot diseases of cereals in southern Finland in 1975-1978. 
Ann. Agric. Fenn. 19: 223-253.

Parmeter, J. R., Jr., Sherwood, R. T. \& Platt, W. D. 1969. Anastomosis grouping among isolates of Thanatephorus cucumeris. Phytopath. 59: 1270-1278.

Petrie, G. A. 1974. Diseases of Brassica species in Saskatchewan, 1970-72: III. Stem and root rots. Can. Pl. Dis. Surv. 53: 99-92.

RAABE, A. 1939. Untersuchungen über pilzparasitäre Krankheiten von Raps und Rübsen. Zbl. Bakt. Abt. 2, c, 1-3, pp. 35-52.

Rawlinson, C. J. \& Muthyalu, G. 1979. Diseases of winter oil-seed rape: occurence, effects and control. J. agric. Sci., Camp. 93: 593-606.

SEPPÃNEn, E. 1979. Tautiryhmä perunaseitti. Koetoim. ja Käyt. 27. 11. 1979 p. 44.
Svensson, C. 1982. Skadesvampar i oljevăxter, biologi och bekämpningsmőjligheter. Växtskyddsrapporter, Jordbruk 20: 60-70.

TAHVONEN, R. 1979. Seed-borne fungi on cruciferous cultivated plants in Finland and their importance in seedling raising. J. Sci. Agr. Soc. Finl. 51: 327-379.

Weinhold, A. R., Dodman, R. L. \& Bowman, T. 1972. Influence of exogenous nutrition on virulence of $R \mathrm{hi}$ zoctonia solani. Phytopath. 62: 278-281.

YLIMÁKI, A. 1967. Root rot as a cause of red clover decline in leys in Finland. Ann. agr. Fenn. 6: (Suppl. 1) $59 \mathrm{p}$.

Ms received April 24, 1984

\section{SELOSTUS}

\section{Rhizoctonia solani kevätrypsin ja -rapsin taimipoltteen aiheuttajana}

\author{
Risto Tahvonen*, Jukka Hollo*, \\ Asko Hannukkala ja Aarne Kurppa*
}

Helsingin yliopiston kasvipatologian laitos, 00710 Helsinki 71

Kevătrypsin ja -rapsin viljely lisăăntyi voimakkaasti 1970-luvulla Suomessa, mutta năită kasveja vaivaavat taudit ovat jăaneet tutkimuksessa văhălle huomiolle. Kasvipatologian laitoksen vuoroviljelykokeessa Viikissä on taimipolte ollut kevătrypsin vuosittainen tauti. Tämăn vuoksi paaătettiin selvittảă, onko tilanne sama kảytănnön viljelmillă.

Kevătrypsi ja -rapsi viljelmiltă kerăttiin vuosina 1981 ja 1982 taiminăytteită kasvien ollessa $2-4$ lehtiasteella. Taimien tautisuus maaăritettiin ja sairaista kasveista tehtiin sienieristyksiä. Lisăksi vuonna 1981 kerăttiin pelloilta maanăytteet, joissa tehtiin kahdessa lämpötilassa $\left(+11^{\circ} \mathrm{C} \mathrm{ja}+25^{\circ} \mathrm{C}\right)$ taimikasvatuksia.

Rhizoctonia solani Kühn oli yleisin taimipoltteisista kevătrypseistă ja -rapseista eristetty sieni sekă vuoroviljelykokeesta ettă pelloilta kerătyistă năytteistă. $R$. sola$n i$ oli myős voimakkain taimipoltteen aiheuttaja patogeenisuustesteissă. Patogeenisuustesteissä perunalta, salaatilta ja ohralta eristetyt $R$. solani - isolaatit eivăt olleet niin voimakkaita taimipoltteen aiheuttajia kuin ke-

* Uusi osoite: Kasvitautiosasto, MTTK, 31600 Jokioinen vătrypsiltä ja -rapsilta eristetyt isolaatit. Fusarium -sieniă eristettiin myös yleisesti, mutta vain $F$. avenaceum Sacc. oli selvăsti kevătrypsin ja -rapsin patogeeni. Koska siemenlevintäisten taimipoltteen aiheuttajien merkitys năyttaaă văhăiseltă aikaisemmin Suomessa tehtyjen havaintojen ja tämăn tutkimuksen sienieristysten perusteella, on kevătrypsin ja -rapsin siementen tiraamipeittaus kyseenalainen toimenpide.

Taimipoltetta esiintyi tutkimusjaksona 1979-82 vuosittain kasvipatologian laitoksen vuoroviljelykokeessa. Myős kàytănnőn viljelmiltă tehtyjen havaintojen mukaan on taimipolte yleinen tauti. Vuonna 1981 tutkituista 62 pellosta 56 pellolla esiintyi taimipoltetta ja vuonna 1982 tutkituista 50 pellosta 46 pellolla esiintyi tătă tautia. Taimipoltteisia taimia oli keskimäärin $10 \%$ pelloilla. Peltoja, joilla oli sairaita kasveja $16-30 \%$, oli kumpanakin vuotena noin $30 \%$ ja peltoja, joilla oli taimipoltteisia taimia yli $30 \%$, oli vastaavasti noin $6 \%$. Maanalaisen taimipoltteen măărăă ei voitu măărittảă kerăttăessă kasvinåytteită pelloilta ja vuoroviljelykokeesta. Peltomaissa tehdyissă taimikasvatuksissa pystyttiin arvioimaan verrannemaiden avulla maanalaisen tai- 
mipoltteen suuruus. Matalassa lämpötilassa kuoli maanalaiseen taimipoltteeseen keskimäärin $14.9 \%$ taimista, mikă oli merkittävăsti enemmăn kuin korkeassa lämpötilassa maanalaiseen taimipoltteeseen kuolleiden taimien luku (4.8\%).

Vuoroviljelykokeessa taimipoltteisten kevătrypsien maaărä lisăäntyi, kun kevătrypsin viljelykerrat samalla paikalla lisaaăntyivăt. Sama ilmiō oli havaittavissa myös käytănnön viljelmillă.

Saatujen tulosten perusteella taimipolte harventaa kevătrypsi- ja -rapsikasvustoja sekă hidastaa taimien alkukehitystä. $R$. solani -sienen käyttäytyminen rypsiviljakierrossa vaatii kuitenkin lisătutkimuksia. 